\title{
Growth Regulator on Rooting and Development of Cucumber Seedlings (Cucumis sativus)
}

${ }^{1}$ Alberto Ricardo Stefeni, ${ }^{2}$ Marciéli da Silva, ${ }^{3}$ AlexandreHack Porto, ${ }^{4}$ Wélida Tomazoni Keller, ${ }^{5}$ Rayanah StivalSvidzinski, ${ }^{6}$ Claudia Manteli

${ }^{I}$ Department of Agroecosystem, Federal Technological University of Paraná (UTFPR), DoisVizinhos, PR, 85660-000, Brazil.

${ }^{2}$ Department of Agronomy, Federal Technological University of Paraná (UTFPR), PatoBranco, PR, 85503-390, Brazil.

${ }^{3}$ Department of Agronomy, Federal Technological University of Paraná (UTFPR), PatoBranco, PR, 85503-390, Brazil.

${ }^{4}$ forestry engineer by the Federal Technological University of Paraná(UTFPR), DoisVizinhos, PR, 85660-000, Brazil.

${ }_{5}^{5}$ Department of Agroecosystem, Federal Technological University of Paraná (UTFPR), DoisVizinhos, PR, 85660-000, Brazil.

${ }^{6}$ Department of Agronomy, Federal Technological University of Paraná (UTFPR), PatoBranco, PR, 85503-390, Brazil.

\section{Address For Correspondence:}

Alberto Ricardo Stefeni, Department of Agroecosystem, Federal Technological University of Paraná (UTFPR), DoisVizinhos, PR, 85660000, Brazil.

\section{ARTICLE INFO}

Article history:

Received 12 October 2017

Accepted 22 December 2017

Available online 31 December 2017

Keywords:

Seed Aplication, Plant Hormones, Bioestimulant.

\begin{abstract}
A B S T R A C T
The use of growth regulators is a practice that can stimulate the growth and development of plants, acting on differentiation and cell elongation. Products with this purpose are sold for application by air and seed treatment. This work aimed at evaluating the growth response of cucumber seedlings to the application of different doses of the Stimulate ${ }^{\circledR}$ growth regulator. The experiment was carried out at UNISEP União de Ensino do Sudoeste do Paraná, DoisVizinhos, in the state of Paraná, Brazil, in protected cultivation. The experiment was conducted in a randomized block design with four replications where five doses of growth regulator: $0.00 ; 0.25 ; 0.50 ; 0.75 ;$ and 1.00 L-1 were evaluated. The seeds were sown in expanded polystyrene trays with 200 cells containing commercial substrate, which were later accommodated in protected cultivation. Seedling height, root system length, fresh weight of shoot and root system were evaluated. It was observed that the 0.00 and 0.75 L-1 doses caused significant effects on the development of air and root part, the doses 0.50 and $1.00 \mathrm{~L}-1$, had positive effects on the development of seedlings.
\end{abstract}

\section{INTRODUCTION}

The cucumber (Cucumis sativus L.), belongs to the family of cucurbits, along with pumpkins, strawberries, zucchinis, watermelons and melons, being composed of $95 \%$ water and much used in culinary. Its origin is still disputed, however, believed to be attributed to India, later its cultivation would have spread to China and European countries. The cucumber usually has a greenish shell (light or dark), cylindrical in shape. Its pulp is light in color with flattened seeds in its surroundings.

One of the main problems for the use of cucumber seeds is the lack of uniformity in germination. With the increasing demand for food in quantity and quality, it is fundamental to adopt new techniques to stimulate production, among them the use of biostimulators, as plant hormones. According to Castro (1998) plant hormone is a group of organic molecules that occurs naturally in plants, which act on the physiological processes of plants, but at low concentrations.

According to Galston\& Davies (1972) and Raven et al. (2001), plant hormones are present in all processes of plant development, acting as chemical messengers. The use of plant hormones in agriculture has shown good results influencing the increase of productivity and cultural management (VIEIRA \& CASTRO, 2002). Growth regulators can be applied directly to stems, leaves, seeds, fruits, and roots (CASTRO \& MELOTO, 1989).

Open Access Journal

Published BY AENSI Publication

(C) 2017 AENSI Publisher All rights reserved

This work is licensed under the Creative Commons Attribution International License (CC BY).

http://creativecommons.org/licenses/by/4.0/

\section{Open Access}

ToCite ThisArticle: Alberto Ricardo Stefeni, Marciéli da Silva, Alexandre Hack Porto, Wélida Tomazoni Keller, Rayanah Stival Svidzinski, Claudia Manteli, Growth regulator on rooting and development of cucumber seedlings (Cucumissativus). Aust. J. Basic \& Appl. Sci., 11(16): 45-48, 2017 
The plant biostimulant still acts efficiently in seed germination, early seedling vigor, root and leaf growth and development, as well as the production of organic compounds (SILVA et al., 2014).

Stimulate ${ }^{\circledR}$ is a growth regulator, being one of the most used at the moment. According to Vieira \& Castro (2002), Stimulate $®$ is composed of indolbutiric acid $(0.05 \mathrm{~g} \mathrm{~L}-1)$, kinetin $(0.09 \mathrm{~g} \mathrm{~L}-1)$ and gibberellic acid $(0.05 \mathrm{~g}$ L-1), they continue that due to the composition, concentration and proportion of their substances, it can stimulate cell division, as well as influence in plant development, making the plants have greater capacity for absorption of water and nutrients.

According to the package label specifications of Stimulate ${ }^{\circledR}$, the use promotes plant development, mainly the development of the root system, positively influencing the absorption of water and essential nutrients for the plants.

The present work had as objective to evaluate different dosages of growth regulators in the development of cucumber seedlings.

\section{MATERIAL AND METHODS}

The experiment was set up in protected cultivation, in the municipality of DoisVizinhos, in the state of Paraná, Brazil, belonging to the UNISEP - União de Ensino do Sudoeste do Paraná, from May 21st to June 12th of 2014.

Five doses of growth regulator $(0.005 \%$ indolebutyric acid, $0.009 \%$ cytokinin and $0.005 \%$ gibberellin) were used in the treatment of cucumber seed: $0.00 ; 0.25 ; 0.50 ; 0.75$; and $1.00 \mathrm{~L}-1$, for each $500 \mathrm{~g}$ of seeds. The treatment was carried out manually with the aid of a plastic bag to homogenize the same. The cultivar Aodai, lot 31214 with $90 \%$ of germinative potential was used.

Immediately after treatment, the seeds were planted in expanded polystyrene trays with 200 cells containing commercial substrate. Twenty cells were used for each plot.

The trays were accommodated in protected culture, covered with low density polyethylene film of 150 microns, additive and closed at the sides with $75 \%$ shading screen.

Five seedlings were collected per plots in three moments, at the second, fourth and sixth days after germination. These were submitted to the evaluation of shoot size and root system, weight of fresh shoot and root mass. For determination of plant height, the measurements were obtained from the lap of the seedling to the apex. To determine the size of the root system, it was measured from the neck of the plant to the tip of the root, with the aid of a digital caliper. In order to obtain the fresh mass data of the aerial part and root system, we used an analytical balance.

The data were submitted to analysis of variance by the F test $(\alpha 0.05)$ and the differences between the means of the treatments, compared by the Tukey test $(\alpha 0.05)$ through the statistical analysis program SISVAR $\mathbb{R}$.

\section{RESULTS AND DISCUSSION}

Treatment at $0.75 \mathrm{~L}-1$ on the second day after germination resulted in a positive result for fresh seedlings, but only differed from the 0.25 L-1 treatment (Table 1). On the fourth day there were no significant differences between treatments. In the sixth day of germination the treatment with $0.75 \mathrm{~L}-1$ obtained superior results compared to the others, while the other results showed small differences between them.

Alleoni et al., (2000), evaluating the application of different doses of plant regulator in common bean, in the number of pod/grains, found that there were no statistical differences between treatments applied in relation to the control. However, they affirm that the dosage of $0.75 \mathrm{~L}-1$, applied via single dose foliage increased by $1.7 \%$ relative to the control. In relation to the mass yield of 1000 grains, they observed that there were significant differences between the treatments where $0.25 \mathrm{~L}-1$ of growth regulator was applied to the seeds and $0.75 \mathrm{~L}-1$ applied in a single foliar dose, when these results were compared with the control.

Studies carried out by Oliveira et al. (1998), applying growth regulators in the bean crop, observed that there was no increase in productivity.

Table 1: Mass of the fresh matter of the aerial part of the plant $(\mathrm{g})$, in different dosages of growth regulator for the production of cucumber seedlings.Unisep - Dois Vizinhos - PR.

\begin{tabular}{llll}
\hline Doses $\left(\mathrm{L}^{-1}\right)$ & $2^{\text {nd }}$ dayaftergermination & $4^{\text {th }}$ dayaftergermination & $6^{\text {ns }}$ \\
\hline 0,00 & $0,20 \mathrm{ab}$ & 0,73 & $0,40 \mathrm{ab}$ \\
0,25 & $0,19 \mathrm{~b}$ & 0,23 & $0,33 \mathrm{abc}$ \\
0,50 & $0,20 \mathrm{ab}$ & 0,23 & $0,31 \mathrm{bc}$ \\
0,75 & $0,27 \mathrm{a}$ & 0,23 & $0,42 \mathrm{a}$ \\
1,00 & $0,20 \mathrm{ab}$ & 0,21 & $0,28 \mathrm{c}$ \\
\hline CV $(\%)$ & 15,94 & 7,95 & 12,53
\end{tabular}

${ }^{n s}$ Not significant, averages followed by the same letter do not differ from each other,

* Averages followed by distinct letters in the column differ from each other by Tukey test $(\alpha=0,05)$. 
For seedling height (Table 2), the results at two and four days after the beginning of germination did not show significant differences between the applied doses, however on the sixth day the treatment in which the product was not used, obtained statistically similar results to the $0.75 \mathrm{~L}-1$ dose. The doses 0.25 and $0.50 \mathrm{~L}-1$ did not differ among themselves and the highest dose had the lowest result. Thus, it can be stated that for seedling growth, there is no need for product use, since the control treatment showed good results.

The use of growth bioregulators in crops in general generates many controversies about their performance. In the soybean crop Bertolin et al. (2010), states that the use of Stimulate ${ }^{\circledR}$ increased productivity. Dario et al. (2005), using Stimulate ${ }^{\circledR}$ in the same culture did not obtain significant results.

Table 2: Aerial shoot height $(\mathrm{cm})$, in different dosages of growth regulator, for the production of cucumber seedlings.Unisep - DoisVizinhos

\begin{tabular}{llll}
\multicolumn{1}{c}{$\mathrm{PR}$} & $2^{\text {nd }}$ dayaftergermination $^{\mathrm{ns}}$ & $4^{\text {th }}$ dayaftergermination $^{\text {ns }}$ & $6^{\text {th }}$ dayaftergermination* $^{*}$ \\
\hline${\text { Doses }\left(\mathrm{L}^{-1}\right)}_{0,00}$ & 3,40 & 7,17 & $4,60 \mathrm{a}$ \\
0,25 & 3,35 & 6,91 & $4,15 \mathrm{ab}$ \\
0,50 & 3,27 & 7,15 & $4,37 \mathrm{ab}$ \\
0,75 & 3,52 & 7,92 & $4,75 \mathrm{a}$ \\
1,00 & 3,27 & 7,35 & $3,87 \mathrm{~b}$ \\
\hline CV $(\%)$ & 7,95 & 9,08 & 6,73
\end{tabular}

${ }^{\mathrm{ns}}$ Not significant, averages followed by the same letter do not differ from each other,

* Averages followed by distinct letters in the column differ from each other by Tukey test $(\alpha=0,05)$.

In relation to the fresh matter mass of the root system (Table 3), it can be observed that on the second and fourth day after germination there were no significant differences, on the sixth day the treatments with a dosage of $0.25,0.50$ and $1.00 \mathrm{~L}-1$, did not differentiate between them, the dose $0.75 \mathrm{~L}-1$ and the control treatment presented better results and did not differ from each other. Bernardes et al. (2010), Mortele et al. (2008) and Baldo et al. (2009), evaluated the use of bioregulators in common bean, cotton and soybean, noting that there was no increase in the productivity of these crops when compared to the control.

However, Abrantes et al. (2011), Bertolin et al. (2010), Albrecht et al. (2009) and Palangana et al. (2012), affirm that they obtained significant results in productivity increase in cotton, soybean, pepper and common bean crops. Mortele et al. (2008), emphasizes that the efficiency of the product depends on the adverse climatic conditions.

Table 3: Mass of the fresh matter of the root system ( $\mathrm{g}$ ) in different dosages of growth regulator, for the production of cucumber seedlings.Unisep - DoisVizinhos - PR

\begin{tabular}{llll}
\hline Doses $\left(\mathrm{L}^{-1}\right)$ & $2^{\text {nd }}$ dayaftergermination ${ }^{\text {ns }}$ & $4^{\text {th }}$ dayaftergermination & $6^{\text {ns }}$ dayaftergermination* \\
\hline 0,00 & 0,067 & 0,087 & $0,22 \mathrm{a}$ \\
0,25 & 0,057 & 0,08 & $0,11 \mathrm{~b}$ \\
0,50 & 0,067 & 0,07 & $0,13 \mathrm{~b}$ \\
0,75 & 0,057 & 0,09 & $0,19 \mathrm{a}$ \\
1,00 & 0,062 & 0,07 & $0,12 \mathrm{~b}$ \\
\hline $\mathrm{CV}(\%)$ & 17,40 & 12,73 & 13,73 \\
\hline
\end{tabular}

${ }^{\mathrm{ns}}$ Not significant, averages followed by the same letter do not differ from each other,

* Averages followed by distinct letters in the column differ from each other by Tukey test $(\alpha=0,05)$.

At the second and fourth days after the beginning of germination, the doses did not present significant differences, but on the sixth day after germination, the control treatment showed higher growth of the root system than the others (Table 4). Candido et al. (2012), analyzing the use of Stimulate® in canelinha stakes where they were immersed in the solution with a concentration of $5 \mathrm{~mL} \mathrm{L-1}$, not obtaining significant results compared to the control, among the variables analyzed by the same dry mass of roots.

In the soybean crop (Glycine max) Cato (2006), with the use of auxins obtained positive results adding weight in the dry mass of roots.

Table 4: Length of the root system $(\mathrm{cm})$, in different dosages of growth regulator, for the production of cucumber seedlings.Unisep DoisVizinhos - PR.

\begin{tabular}{llll}
\hline Doses $\left(\mathrm{L}^{-1}\right)$ & $2^{\text {nd }}$ dayaftergermination ${ }^{\text {ns }}$ & $4^{\text {th }}$ dayaftergermination & $6^{\text {ns }}$ \\
\hline 0,00 & 5,80 & 7,17 & 9,80 a \\
0,25 & 7,30 & 6,91 & $7,60 \mathrm{~b}$ \\
0,5 & 6,65 & 7,15 & $8,17 \mathrm{~b}$ \\
0,75 & 7,22 & 7,92 & $9,9 \mathrm{a}$ \\
1,00 & 6,30 & 7,35 & $8,02 \mathrm{~b}$ \\
\hline CV $(\%)$ & 14,45 & 9,08 & 8,54 \\
\hline
\end{tabular}

${ }^{\mathrm{ns}}$ Not significant, averages followed by the same letter do not differ from each other,

* Averages followed by distinct letters in the column differ from each other by Tukey test $(\alpha=0,05)$. 


\section{Conclusion:}

The use of growth regulator affected the development of seedlings only on the sixth day after germination, increasing the weight and length of fresh matter of aerial part and root system of cucumber seedlings.

The $0.75 \mathrm{~L}-1$ dose was highlighted for the four variables evaluated.

\section{Future Studies:}

Evaluate doses of growth regulators in seedlings of cucumber (Cucumissativus) in function of different types of substrates.

\section{REFERENCES}

ABRANTES, F.L., M.E. SÁ, L.C.D. SOUZA, M.P. SILVA, H.M. SIMIDU, M. ANDREOTTI, S. BUZETTI, W.V. VALÉRIO FILHO and N. ARRUDA, 2011. Uso de regulador de crescimento em cultivares de feijão de inverno. Pesq. Agropec. Trop., Goiânia, 41(2): 148-154.

ALLEONI, F., M. BOSQUEIRO and M. ROSSI, 2000. Efeito dos reguladores vegetais de Stimulate no desenvolvimento e produtividade do feijoeiro (Phaseolusvulgaris). Ciências Exatas e da Terra, Ciências Agrárias e Engenharias, Ponta Grossa, 6(1): 23-35.

ALBRECHT, L.P., A.L. BRACCINI, M.R. ÁVILA, M.C. BARBOSA, T.T. RICCI and A.P. ALBRECHT, 2009. Aplicação de biorregulador na produtividade do algodoeiro e qualidade de fibra, Scientia Agraria, Curitiba, 10(3): 191-198.

BALDO, R., S.P.Q. SCALON, Y.B.C.J. ROSA, R.M. MUSSURY, R. BETONI and W.S. BARRETO, 2009. Comportamento do algodoeiro cultivar delta opal sob estresse hídrico com e sem aplicação de regulador de crescimento. Ciênc. Agrotec., Lavras, 33: 1804-1812.

BERNARDES, T.G., P.M. SILVEIRA and M.A.M. MESQUITA, 2010. Produtividade do feijoeiro irrigado devido a reguladores de crescimento e culturas antecessoras de cobertura. Bragantia, Campinas, 69(2): 371-375.

BERTOLIN, D.C., M.E. SÁ, O. ARF, E. FURLANI JUNIOR, A.S. COLOMBO and F.L.B.M. CARVALHO, 2010. Aumento da produtividade de soja com a aplicação de bioestimulante. Bragantia, Campinas, 69(2): 339-347.

CANDIDO, W.D.S., R.C.P. SILVA, S.S.S. MAIA, A.C. SILVA and M.F.B. COELHO, 2012. Propagação da canelinha (CrotonzehntneriPaxetHoffm.) por estacas caulinares. Revista Verde, Mossoró, 7(2): 45-49.

CASTRO, P.R.C., 1998. Utilização de reguladores vegetais na fruticultura, na horticultura e em plantas ornamentais. Piracicaba: ESALQ-DIBD, pp: 92.

CASTRO, P.R.C. and E. MELLOTO, 1989. Bioestimulantes e hormônios aplicados via foliar. In: Boareto A. E. Rosolem C. A. Adubação foliar. Campinas: Fundação Cargill, 1(8): 191-235.

CATO, S.C. and P.R. CASTRO, C.E. DE, 2006. Redução da altura de plantas de soja causada pelo ácido 2,3,5-triiodobenzóico. Ciência Rural, Santa Maria, 36(3): 981-984.

DARIO, G.J.A., T.N. MARTIN, D. DOURADO NETO, P. MANFRON, R.A.G. BONNECARRÈRE and P.E.N. CRESPO, 2005. Influência do uso de fitorregulador no crescimento da soja.Revista da FZVA. Uruguaiana, 12(1): 63-70.

GALSTON, A.W. and P.J. DAVIES, 1972. Mecanismos de controle no desenvolvimento vegetal. São Paulo: Edgard Blücher USP, p: 171.

MORTELE, L.M., R.F. SANTOS, E. LUCCA, A. BRACCINI, C.A. SCAPIM and M.C. BARBOSA, 2008. Efeito da aplicação de biorregulador no desempenho agronômico e produtividade da soja. Acta Sci. Agron., Maringá, 30(supl.): 701-709.

OLIVEIRA, R.F., L. PACE and C.A. ROSOLEM, 1998. Produção e estado nutricional do feijoeiro em função da aplicação de um promotor de crescimento. Científica, São Paulo, 26(1/2): 203-212.

PALANGANA, F.C., E.S. SILVA, R. GOTO and E.O. ONO, 2012. Ação conjunta de citocinina, giberelina e auxina em pimentão enxertado e não enxertado sob cultivo protegido. Hortic. Bras. Vitória da Conquista, 30(4): 751-755.

RAVEN, P.H., R.F. EVERT and S.E. EICHHORN, 2001. Biologia vegetal, Rio de Janeiro, Guanabara Koogan, p: 906.

SILVA, M.J.R., A.C.B. BOLFARINI, L.F.O.S. RODRIGUES and E.J.D. ONO RODRIGUES, 2014. Formação de mudas de melância em função de diferentes concentrações e formas de aplicação de mistura de reguladores vegetais. Scientia Plena. Aracaju, 10(10): 01-09.

VIEIRA, E.L. and P.R.C. CASTRO, 2002. Estimulante no desenvolvimento inicial de plantas de algodoeiro (Gossypiumhirsutum L.). Piracicaba: USP. Departamento de CiênciasBiológicas, p: 3. 